\title{
Autopsy Case of Meningoencephalomyelitis Associated With Glial Fibrillary Acidic Protein Antibody
}

Mai Yamakawa, MD, Keenan O. Hogan, MD, John Leever, MD, and Yasir N. Jassam, MBChB, MRCP (UK)

Neurol Neuroimmunol Neuroinflamm 2021;8:e1081. doi:10.1212/NXI.0000000000001081
Correspondence

Dr. Jassam

yasir.jassam@hoag.org

\section{Abstract}

\section{Background and Objectives}

To describe the autopsy findings and neuropathologic evaluation of autoimmune meningoencephalomyelitis associated with glial fibrillary acidic protein (GFAP) antibody.

\section{Methods}

We reviewed the clinical course, imaging, laboratory, and autopsy findings of a patient with autoimmune meningoencephalomyelitis associated with GFAP antibody who had a refractory course to multiple immunosuppressive therapies.

\section{Results}

The patient was a 70-year-old man who was diagnosed as GFAP antibody-associated autoimmune meningoencephalomyelitis. MRI of the head showed linear perivascular enhancement in the midbrain and the basal ganglia. Despite treatment with high-dose corticosteroids, plasma exchange, IV immunoglobulins, and cyclophosphamide, he died with devastating neurologic complications. Autopsy revealed a coexistent neuroendocrine tumor in the small intestine and diffuse inflammation in the brain parenchyma, perivascular spaces, and leptomeninges, with predominant T-cells, macrophages, and activated microglia. B-cells and plasma cells were absent. There was no astrocyte involvement with change in GFAP immunostaining.

\section{Discussion}

This case illustrates autoimmune meningoencephalomyelitis associated with GFAP antibody in the CSF and coexistent neuroendocrine tumor. The autopsy findings were nonspecific and did not demonstrate astrocyte involvement. Further accumulation of cases is warranted to delineate the utility and pathogenic significance of the GFAP autoantibody.

From the Department of Neurology (M.Y., J.L., Y.N.J.); Department of Pathology and Laboratory Medicine (K.O.H.); Department of Radiology (J.L.), University of Kansas Medical Center; and Hoag Memorial Hospital Presbyterian (Y.N.J.), Pickup Family Neuroscience Institute, Newport Beach, CA.

Go to Neurology.org/NN for full disclosures. Funding information is provided at the end of the article. 


\section{Glossary}

AQP-4 = aquaporin 4; CLIPPERS = chronic lymphocytic inflammation with pontine perivascular enhancement responsive to steroids; GFAP = glial fibrillary acidic protein; WDNET = well-differentiated neuroendocrine tumor.

\section{Case}

A 70-year-old Caucasian man with dyslipidemia and depression presented to the emergency department with hand tremors for several months, progressive imbalance and falls, confusion, and insomnia for 2 weeks. He was alert and oriented with psychomotor slowing, with a temperature of $37.5^{\circ} \mathrm{C}$, tachycardia of 109 beats per minute, and restlessness. Neurologic examination revealed increased tone in the neck and the left leg, diffuse myoclonic jerks, bilateral endpoint tremor, and symmetric hyperreflexia. Admission laboratory test results were significant for mild leukocytosis of $12.1 \times$ $10^{3} / \mathrm{mL}$ and hyponatremia of $126 \mathrm{mEq} / \mathrm{L}$; thyroid stimulating hormone, glucose, urinalysis, and creatine kinase were normal. CT head was unremarkable.

Initially, serotonin syndrome from concurrent bupropion and citalopram use was suspected, and cyproheptadine was started. However, he became lethargic and febrile $\left(39.1^{\circ} \mathrm{C}\right)$ on day 2 of admission, requiring endotracheal intubation. CSF analysis on day 2 showed lymphocytic leukocytosis (nucleated cells $\left.120 / \mathrm{mm}^{3}\right)$ and elevated protein $(167 \mathrm{mg} / \mathrm{dL})$. Abbreviated hospital course is shown in Figure 1. Hyponatremia was corrected with fluid resuscitation and cessation of citalopram not requiring prolonged fluid restriction. MRI of the head showed linear symmetric perivascular enhancement in bilateral crus cerebri and basal ganglia that were not present 10 days before admission (Figure 2, A-C), as well as thin subdural fluid collections in the posterior convexity concerning for subdural empyema and meningitis (Figure 2D). Magnetic resonance angiogram of the head was normal. MRI of the thoracic spine on day 6 showed long segment thoracic cord signal abnormalities with a possible enhancement (Figure 2F). Extensive infectious and rheumatological assessments were negative. SARS-CoV-2 polymerase chain reaction was not performed because this presentation occurred before the pandemic.

The patient was started on IV methylprednisolone $1 \mathrm{~g} /$ day for 5 days with a protracted taper. Findings on the MRI of the head and T-spine continued to improve (Figure 2, D and E). Inflammation in CSF peaked on day 14 with 660/ $\mathrm{mm}^{3}$ lymphocytes, with 5 oligoclonal bands, and IgG synthesis rate of 21.22. The patient underwent 3 sessions of plasma exchange. On day 24, the autoimmune encephalitis CSF panel came back positive for glial fibrillary acidic protein (GFAP) antibody, and a diagnosis of GFAP antibody-associated meningoencephalomyelitis was made. Anti-NMDA receptor antibody was negative. IV immunoglobulins were given, followed by cyclophosphamide 500 $\mathrm{mg} / \mathrm{m}^{2}$. Whole-body CT, PET-CT, and scrotal ultrasound were negative for malignancy. Despite the improvement in CSF and MRI findings, the patient continued to have severe myoclonus, requiring continuous sedation and 3 antiseizure drugs; EEG developed bifrontal epileptic discharges while on these medications. The patient was palliatively extubated and died on day 47 . His family agreed to proceed with an autopsy.

\section{Autopsy Findings}

The autopsy revealed acute pneumonia and undiagnosed well-differentiated neuroendocrine tumor (WDNET) in the small intestine; this was negative for GFAP immunohistochemistry. Gross examination of the brain demonstrated diffuse mild leptomeningeal fibrosis over the convexities with scattered arachnoid granulations. Sectioning revealed severe edema of the cerebral hemispheres with enlarged gyri, narrow sulci, and central herniation affecting the midbrain. A thorough microscopic examination revealed variable degrees of inflammation involving the entire brain except for the cerebellum. The inflammatory infiltrates were perivascular with extension into the parenchyma (Figure 3A). There was no evidence of demyelination or loss of GFAP stain, nor

Figure 1 Schema of Hospital Course With Cerebrospinal Fluid White Blood Cells and Protein, and Attempted Treatments

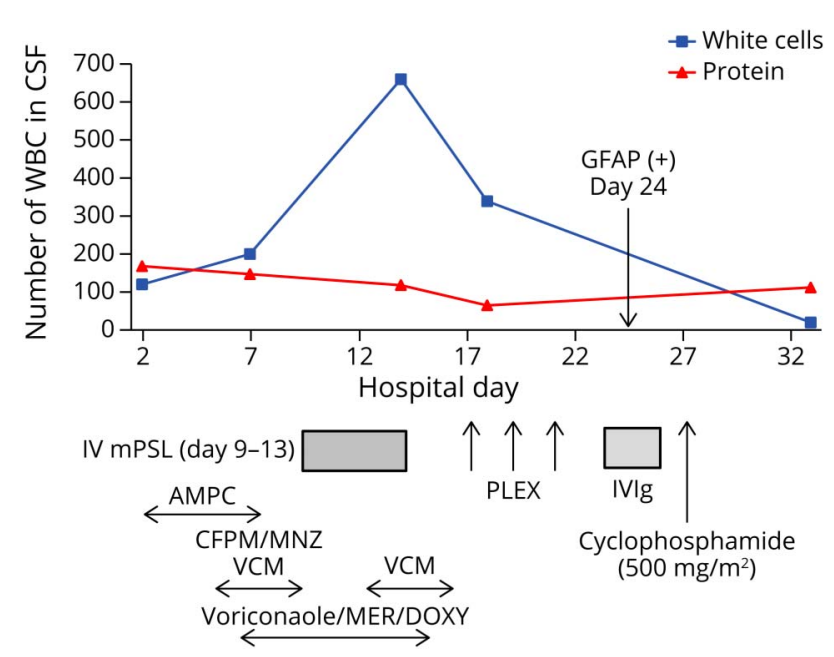

$X$-axis represents hospital day, and Y-axis represents WBC in cerebral spinal fluid (CSF). AMPC = amoxicillin; CFPM = cefepime; DOXY = doxycycline; Ig = immunoglobulin; MER = meropenem; MNZ = metronidazole; $\mathrm{mPSL}=$ methylprednisolone; $\mathrm{PLEX}=$ plasma exchange; $\mathrm{VCM}=$ vancomycin; $\mathrm{WBC}=$ white blood cell . 

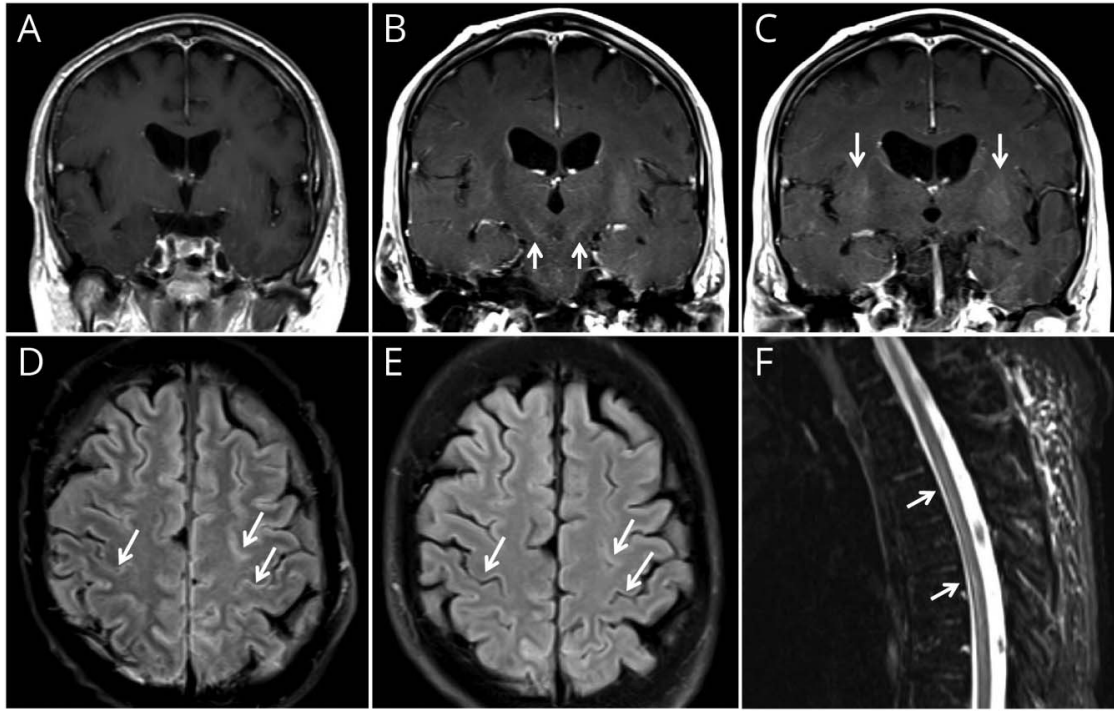

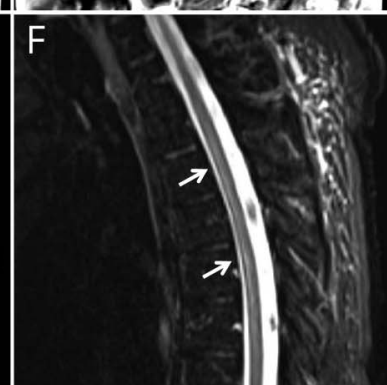

(A) MRI of the head, T1 postcontrast 10 days before the admission without perivascular enhancement; (B) MRI of the head T1 postcontrast on day 4 of admission with linear perivascular enhancement in crus cerebri, and (C) in basal ganglia, pointed with arrows; (D) MRI of the head FLAIR on day 4 of admission showing areas of abnormal sulcal FLAIR hyperintensity along the cerebral convexities with pointed arrows; (E) MRI of the head FLAIR on day 26 of admission with resolution of sulcal abnormality; (F) MRI thoracic spine T2 on day 6 of admission, T2, sagittal view showing longitudinal intrinsic thoracic cord hyperintensity. FLAIR = fluid-attenuated inversion recovery. fragmented or macrophage-engulfed astrocytes; GFAP stain showed focal moderate cortical gliosis and some subpial gliosis. Aquaporin 4 (AQP-4) stain was not performed. There was no vasculitis or necrosis. The inflammatory cells were a mixture of $\mathrm{CD}^{+}$and $\mathrm{CD}^{+} \mathrm{T}$ lymphocytes and macrophages (Figure 3, B and C). No B lymphocytes or plasma cells were identified. CD68 immunostain showed prominent microglial activation and macrophages throughout the cortex and white matter, as well as highlighting perivascular and leptomeningeal infiltrates (Figure 3D). There were diffuse severe acute hypoxic-ischemic leukoencephalopathy and severe edema throughout the cortices. There were no Lewy bodies, inclusions, senile plaques, or neurofibrillary tangles as demonstrated by $\alpha$-synuclein, $\beta$-amyloid, and Tau immunostains. The spinal cord was not examined.

\section{Methods}

\section{Standard Protocol Approvals, Registrations, and Patient Consents}

This was a case report and no IRB approval was needed. The consent for autopsy was obtained from the patient's wife.

Figure 3 Neuropathologic Finding on Autopsy

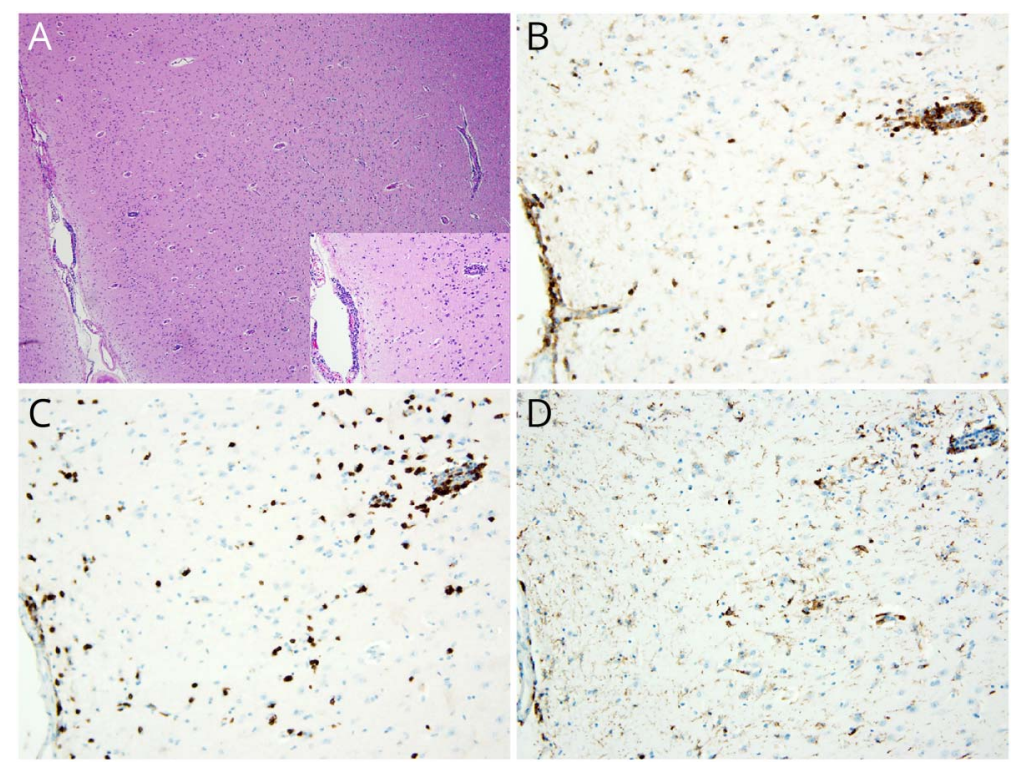

Sections are from hippocampus. (A) H-E stain, 40x, representing inflammation in perivascular space, parenchyma, and leptomeningeal space; the inset represents $\mathrm{H}-\mathrm{E}$ stain, 200x. (B) CD4 immunostain, 200x, representing helper Tcells; (C) CD8 immunostain, 200x, representing cytotoxic Tcells; (D) CD68 immunostain, 200×, representing microglial activation. $\mathrm{H}-\mathrm{E}=$ hematoxylin-eosin. 


\begin{tabular}{|c|c|c|c|c|c|c|c|c|c|c|}
\hline Reference & $\mathbf{N}$ & $\begin{array}{l}\text { GFAP } \\
\text { antibody }\end{array}$ & Concurrent auto-antibodies & $\begin{array}{l}\text { Response to } \\
\text { immunosuppressive } \\
\text { therapies }\end{array}$ & $\begin{array}{l}\text { Type of } \\
\text { specimen }\end{array}$ & $\begin{array}{l}\text { Location of } \\
\text { inflammation }\end{array}$ & Astrocyte involvement & Neuron loss & Demyelination & Types of inflammatory cells \\
\hline $\begin{array}{l}\text { Long } \\
\text { et al. }\end{array}$ & 19 & CSF, CBA & $\begin{array}{l}13 \text { patients had serum } \\
\text { antinuclear/endothelial cell/ } \\
\text { cardiolipin/neutrophil } \\
\text { cytoplasmic/double-stranded } \\
\text { DNA/RA33/SS-A/Ro52 } \\
\text { antibodies }\end{array}$ & $\begin{array}{l}18 / 19 \text { patients were } \\
\text { initially treated with } \\
\text { corticosteroids, and } 11 \\
\text { received IVIG; all } \\
\text { discharged, } 2 \text { were lost to } \\
\text { follow-up }\end{array}$ & $\begin{array}{l}\text { Brain } \\
\text { biopsy; } 4\end{array}$ & $\begin{array}{l}\text { Perivascular } \\
\text { space, brain } \\
\text { parenchyma, } \\
\text { Virchow-Robin } \\
\text { spaces }\end{array}$ & $\begin{array}{l}\text { Complete loss of AQP-4 } \\
\text { and GFAP in a patient; } \\
\text { local decreased GFAP and } \\
\text { AQP- } 4 \text { were found in the } \\
\text { other } 3 \text { patients } \\
\text { Reactive hypoplasia }\end{array}$ & Yes & Yes & $\begin{array}{l}\text { Lymphocytes, monocytes, } \\
\text { neutrophils, and activated } \\
\text { microglias } \\
\text { Prominent perivascular B cells } \\
\left(\mathrm{CD}^{+} 0^{+}\right) \text {and T cells }\left(\mathrm{CD}^{+}\right) \\
\text {distributed in the brain } \\
\text { parenchyma } \\
\text { Abundant antibody-secreting } \\
\text { cells }(\mathrm{CD} 138+) \text { were noted in the } \\
\text { Virchow-Robin spaces }\end{array}$ \\
\hline $\begin{array}{l}\text { lorio } \\
\text { et al. } .^{5}\end{array}$ & 22 & $\begin{array}{l}\text { Serum } \\
\text { and/or } \\
\text { CSF, IFA, } \\
\text { CBA }\end{array}$ & $\begin{array}{l}5 \text { patients (GABAAR-IgG, 1; Yo- } \\
\text { IgG, 1; IgG binding to } \\
\text { unclassified antigens (UNCA), } \\
\text { 3) }\end{array}$ & $\begin{array}{l}\text { Response in } 16 \text { patients } \\
(84 \%)\end{array}$ & $\begin{array}{l}\text { Meningeal } \\
\text { biopsy; } 1\end{array}$ & N/A & $\mathrm{N} / \mathrm{A}$ & $\mathrm{N} / \mathrm{A}$ & N/A & $\begin{array}{l}\text { Necrotizing inflammatory } \\
\text { process with } C D 8^{+} \text {lymphocytes, } \\
\text { macrophages, and } \\
\text { multinucleated giant cells }\end{array}$ \\
\hline Shu et al. ${ }^{4}$ & 1 & $\begin{array}{l}\text { CSF, IFA } \\
\text { and CBA }\end{array}$ & None & $\begin{array}{l}\text { No improvement after } \\
\text { corticosteroids and IVIG }\end{array}$ & $\begin{array}{l}\text { Brain } \\
\text { biopsy }\end{array}$ & $\begin{array}{l}\text { Perivascular } \\
\text { space, white } \\
\text { and gray } \\
\text { matter }\end{array}$ & None & None & None & $\begin{array}{l}\text { Abundant } \mathrm{CD} 3^{+} \text {and } \mathrm{CD} 4^{+} \mathrm{T} \\
\text { lymphocytes; a few } \mathrm{CD} 8^{+} \mathrm{T} \text { cells } \\
\text { and } \mathrm{CD} 20^{+} \mathrm{B} \text { lymphocytes; } \\
\text { scattered } \mathrm{CD} 68^{+} \text {macrophages } \\
\text { and CD138 + plasma cells }\end{array}$ \\
\hline $\begin{array}{l}\text { Current } \\
\text { case }\end{array}$ & 1 & $\begin{array}{l}\text { CSF, IFA } \\
\text { and CBA }\end{array}$ & None & $\begin{array}{l}\text { No improvement after } \\
\text { corticosteroids, IVIG, } \\
\text { plasma exchange, and } \\
\text { cyclophosphamide }\end{array}$ & $\begin{array}{l}\text { Autopsy, } \\
\text { whole } \\
\text { brain }\end{array}$ & $\begin{array}{l}\text { Perivascular } \\
\text { space, brain } \\
\text { parenchyma }\end{array}$ & None & $\begin{array}{l}\text { Hypoxic-ischemic } \\
\text { leukoencephalopathy }\end{array}$ & None & $\begin{array}{l}\mathrm{CD} 4^{+} \text {and } \mathrm{CD} 8^{+} \mathrm{T} \text { lymphocytes } \\
\text { and macrophages; } \mathrm{CD} 68^{+} \\
\text {activated microglias } \\
\text { macrophages }\end{array}$ \\
\hline
\end{tabular}

Abbreviations: CBA = cell-based assay; GFAP = glial fibrillary acidic protein; IFA = immunofluorescent assay; IVIG = IV immunoglobulin. 


\section{Data Availability}

All the data appear in the article.

\section{Discussion}

This article reports a case of autoimmune meningoencephalomyelitis with a positive GFAP antibody with an autopsy and complete neuropathologic evaluation of the whole brain. Autoimmune GFAP astrocytopathy defined by GFAP IgG positivity in the CSF is an emerging disease entity first described in 2016 as angiography-negative, corticosteroidresponsive subacute meningoencephalomyelitis with CSF lymphocytic pleocytosis. ${ }^{1,2}$ Neuropathologic evaluation of the condition is limited to brain and meningeal biopsies of 5 patients to date, as summarized in Table $1 .^{3-5}$ One case series from China showed astrocytopathy with a loss or decrease of GFAP and AQP-4 stain with GFAP antibody in CSF, notably with concurrent autoantibodies such as p-ANCA, antiendothelial cell, anti-MOG, antinuclear, anti-SSA, and antiRo-52 antibodies in 3 of 4 cases. $^{3}$ In our case, AQP-4 immunostaining or antemortem serum testing was not performed; however, there was no signs of astrocyte involvement with GFAP immunostaining, including loss or decrease of GFAP, fragmentation, or phagocytosis of the astrocytes. Our case goes against the causal pathogenicity to astrocyte decay of the GFAP antibody in CSF, in contrast to the well-documented pathogenicity of AQP-4 antibody in neuromyelitis optica spectrum disorders resulting in astrocytopathy. ${ }^{6-9}$

The neuropathologic finding of our case was relatively nonspecific. Differential diagnoses of the neuropathologic findings include chronic lymphocytic inflammation with pontine perivascular enhancement responsive to steroids (CLIPPERS) and anti-NMDA encephalitis. In CLIPPERS, the mainstay of inflammatory cells is CD4 T-cells, indicating possible major histocompatibility complex class II-restricted antigen presentation or allergic reaction, along with microglia, histiocytes, and B cells. Vascular damage with necrosis, fibrin deposition astrocytic fragmentation, neuronophagia, and focal demyelination have been seen. ${ }^{10}$ Our case with inflammation in gray and white matter of whole brain contradicts CLIPPERS, which has the predilection to the white matter of the hindbrain. As for NMDA encephalitis, the hallmark of pathology is perivascular B-cell cuffing and scattered $\mathrm{T}$ cells in the parenchyma, which were not seen in our autopsy. Our case possibly was paraneoplastic autoimmune encephalitis with the GFAP-negative WDNET; this could infer that the GFAP antibody in the CSF was a byproduct of the ongoing inflammation, and rather not a causative cross-reacting autoantibody induced by the concurrent neoplasm.

Periventricular perivascular enhancement is perceived as a classic finding of autoimmune astrocytopathy seen in half of cases; however, it is unknown if this directly indicates astrocyte involvement. ${ }^{2,3,11}$ In our case, the perivascular enhancement in the midbrain and basal ganglia on MRI did not correlate with astrocyte involvement in the autopsy. Collectively, because positive GFAP antibody in CSF or periventricular perivascular enhancement on MRI does not confirm astrocytes involvement in the inflammation, the term "astrocytopathy" should be used carefully until the pathologic demonstration. Nevertheless, we believe that identifying associated autoantibodies would help to guide care of otherwise indistinguishable autoimmune encephalitides, possibly augmenting cancer screening in select cases. Further accumulation of cases is needed to better define this emerging disease entity.

We have important limitations in our report. First, this was a postmortem study after a prolonged disease course, and the cardiopulmonary compromise shortly before death likely affected the pathology with hypoxic-ischemic changes. The extensive immunotherapies also likely altered the pathology findings, evidenced by antemortem oligoclonal bands in the CSF without postmortem B and plasma cells. Finally, we did not assess the spinal cord or stain for AQP-4.

GFAP antibody is implicated in autoimmune meningoencephalitis; however, there is limited evidence that this is the causative antibody provoking downstream inflammation with astrocytes. Our case with CSF-positive GFAP antibody did not have astrocytic involvement in the autopsy, suggesting that GFAP antibody was a bystander autoantibody with the inflammation. The causality of GFAP antibody has to be investigated with more pathologic evaluations of similar cases.

\section{Acknowledgment}

The authors would like to thank the medical intensive care unit team and the neurology consult service, especially Dr. Mohammed Nashatizadeh, Dr. Brennen Bittel, and Dr. Brenton Massey for the compassionate continuity of care, and express gratitude for the family's dedication, through the contribution of their loved one, to the progress of science in neurology, neuroimmunology, and neuropathology. Dr. Yasir N. Jassam's current affiliation is Pickup Family Neuroscience Institute, Hoag Memorial Presbyterian Hospital, Newport Beach, CA, USA.

\section{Study Funding}

The authors report no targeted funding.

\section{Disclosure}

Y.N. Jassam: Janssen Pharmaceuticals speakers bureau, unrelated to this article. The other authors report no disclosures relevant to the manuscript. Go to Neurology.org/NN for full disclosures.

\section{Publication History}

Received by Neurology: Neuroimmunology \& Neuroinflammation January 4, 2021. Accepted in final form July 16, 2021. 


\section{Appendix Authors}

\begin{tabular}{lll}
\hline Name & Location & Contribution \\
\hline $\begin{array}{l}\text { Mai } \\
\text { Mamakawa, }\end{array}$ & $\begin{array}{l}\text { Department of Neurology, } \\
\text { University of Kansas Medical } \\
\text { Center }\end{array}$ & $\begin{array}{l}\text { Drafting/revision of the } \\
\text { manuscript for content, } \\
\text { including medical writing } \\
\text { for content }\end{array}$ \\
\hline $\begin{array}{l}\text { Keenan O. } \\
\text { Hogan, MD }\end{array}$ & $\begin{array}{l}\text { Department of Pathology and } \\
\text { Laboratory Medicine, } \\
\text { University of Kansas Medical } \\
\text { Center }\end{array}$ & $\begin{array}{l}\text { Major role in the } \\
\text { acquisition of data and } \\
\text { analysis or interpretation } \\
\text { of data }\end{array}$ \\
\hline $\begin{array}{l}\text { John Leever, } \\
\text { MD }\end{array}$ & $\begin{array}{l}\text { Department of Neurology, } \\
\text { University of Kansas Medical } \\
\text { Center; Department of } \\
\text { Radiology, University of } \\
\text { Kansas Medical Center }\end{array}$ & $\begin{array}{l}\text { Major role in the } \\
\text { acquisition of data and } \\
\text { analysis or interpretation } \\
\text { of data }\end{array}$ \\
\hline $\begin{array}{l}\text { Yasir N. } \\
\text { Jassam, } \\
\text { MBChB, } \\
\text { MRCP (UK) }\end{array}$ & $\begin{array}{l}\text { Department of Neurology, } \\
\text { University of Kansas Medical } \\
\text { Center; Hoag Memorial } \\
\text { Hospital Presbyterian, Pickup } \\
\text { Family Neuroscience } \\
\text { Institute, Newport Beach, CA; } \\
\text { Dr. Jassam's affiliation has } \\
\text { changed since the } \\
\text { completion of this work. }\end{array}$ & $\begin{array}{l}\text { Drafting/revision of the } \\
\text { including medical writing } \\
\text { interpretation of data }\end{array}$ \\
& & \\
& & \\
& &
\end{tabular}

\section{References}

1. Fang B, McKeon A, Hinson SR, et al. Autoimmune glial fibrillary acidic protein astrocytopathy: a novel meningoencephalomyelitis. JAMA Neurol. 2016;73(11):1297-1307.

2. Flanagan EP, Hinson SR, Lennon VA, et al. Glial fibrillary acidic protein immunoglobulin $\mathrm{G}$ as biomarker of autoimmune astrocytopathy: analysis of 102 patients. Ann Neurol. 2017;81(2):298-309.

3. Long $\mathrm{Y}$, Liang J, $\mathrm{Xu} \mathrm{H}$, et al. Autoimmune glial fibrillary acidic protein astrocytopathy in Chinese patients: a retrospective study. Eur J Neurol. 2018;25(3):477-483.

4. Shu Y, Long Y, Chang Y, et al. Brain immunohistopathology in a patient with autoimmune glial fibrillary acidic protein astrocytopathy. Neuroimmunomodulation. 2018 25(1):1-6.

5. Iorio R, Damato V, Evoli A, et al. Clinical and immunological characteristics of the spectrum of GFAP autoimmunity: a case series of 22 patients. J Neurol Neurosurg Psychiatry. 2018;89(2):138-146.

6. Takano R, Misu T, Takahashi T, Sato S, Fujihara K, Itoyama Y. Astrocytic damage is far more severe than demyelination in NMO: a clinical CSF biomarker study. Neurology. 2010;75(3):208-216.

7. Rossi A, Ratelade J, Papadopoulos MC, Bennett JL, Verkman AS. Consequences of NMO-IgG binding to aquaporin-4 in neuromyelitis optica. Proc Natl Acad Sci U S A. 2012;109(24):E1511, author reply E1512.

8. Misu T, Fujihara K, Kakita A, et al. Loss of aquaporin 4 in lesions of neuromyelitis optica: distinction from multiple sclerosis. Brain. 2007;130(Pt 5):1224-1234.

9. Hinson SR, Romero MF, Popescu BF, et al. Molecular outcomes of neuromyelitis optica (NMO)-IgG binding to aquaporin-4 in astrocytes. Proc Natl Acad Sci USA. 2012;109(4):1245-1250.

10. Dudesek A, Rimmele F, Tesar S, et al. CLIPPERS: chronic lymphocytic inflammation with pontine perivascular enhancement responsive to steroids. Review of an increasingly recognized entity within the spectrum of inflammatory central nervous system disorders. Clin Exp Immunol. 2014;175(3):385-396.

11. Shan F, Long Y, Qiu W. Autoimmune glial fibrillary acidic protein astrocytopathy: a review of the literature. Front Immunol. 2018;9:2802. 


\title{
Neurology \\ Neuroimmunology \& Neuroinflammation
}

\author{
Autopsy Case of Meningoencephalomyelitis Associated With Glial Fibrillary Acidic \\ Protein Antibody \\ Mai Yamakawa, Keenan O. Hogan, John Leever, et al. \\ Neurol Neuroimmunol Neuroinflamm 2021;8; \\ DOI 10.1212/NXI.0000000000001081
}

This information is current as of October 12, 2021

\section{Updated Information \& \\ Services \\ References \\ Subspecialty Collections}

Permissions \& Licensing

Reprints including high resolution figures, can be found at:

http://nn.neurology.org/content/8/6/e1081.full.html

This article cites 11 articles, 3 of which you can access for free at: http://nn.neurology.org/content/8/6/e1081.full.html\#\#ref-list-1

This article, along with others on similar topics, appears in the following collection(s):

All Immunology

http://nn.neurology.org//cgi/collection/all_immunology

Autoimmune diseases

http://nn.neurology.org//cgi/collection/autoimmune_diseases

Paraneoplastic syndrome

http://nn.neurology.org//cgi/collection/paraneoplastic_syndrome

Information about reproducing this article in parts (figures,tables) or in its entirety can be found online at:

http://nn.neurology.org/misc/about.xhtml\#permissions

Information about ordering reprints can be found online:

http://nn.neurology.org/misc/addir.xhtml\#reprintsus

Neurol Neuroimmunol Neuroinflamm is an official journal of the American Academy of Neurology.

Published since April 2014, it is an open-access, online-only, continuous publication journal. Copyright

Copyright $\odot 2021$ The Author(s). Published by Wolters Kluwer Health, Inc. on behalf of the American

Academy of Neurology.. All rights reserved. Online ISSN: 2332-7812.

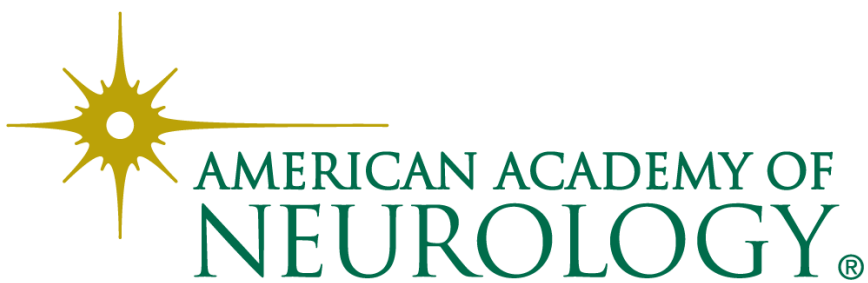

